\title{
Different Faces of Varicella
}

\author{
Suçiçeğinin Farklı Yüzleri
}

\author{
Nurhayat Yakut ${ }^{1}$ (ID), Burhaneddin Şahin'1(ID), Gamze Karagöz' (ID) \\ ${ }^{1}$ Clinic of Pediatric Infectious Diseases, Başakşehir Çam and Sakura City Hospital, İstanbul, Turkey
}

Cite this article as: Yakut N, Şahin B, Karagöz G. Different faces of varicella. J Pediatr Inf 2021;15(1):e63-e64.

A previously healthy 6-year-old girl was admitted with complaints of skin rash and fever. It was learned that the patient's fever and cough started four days ago and vesicular lesions appeared on her trunk. Her body temperature was $38.5^{\circ} \mathrm{C}$. Physical examination revealed a few vesicular lesions on her body (Figure 1A) and bilateral rhonchus on auscultation of the lungs. The patient had one dose varicella vaccine and was diagnosed with varicella. She was started on acyclovir for varicella pneumoniae. The patient's lesions dried up (Figure 1B) and clinical condition was improved.

A 7-year-old girl with the diagnosis of relapsing ALL presented with complaints of skin rash and fever. Physical examina- tion showed disseminated papulovesicular lesions on the trunk, face, and extremities (Figure 2A). She was diagnosed with varicella. Acyclovir treatment was started and continued for 10 days. The patient's lesions transformed into hemorrhagic character and then healed by crusting (Figure 2B, 2C).

Varicella is a childhood disease caused by the varicella-zoster virus It is frequently characterized by vesicular rashes. The number and characteristics of the lesions vary regarding age, immunosuppression, vaccination status and dose. It should be kept in mind that it can progress with complications and can be prevented by vaccination.

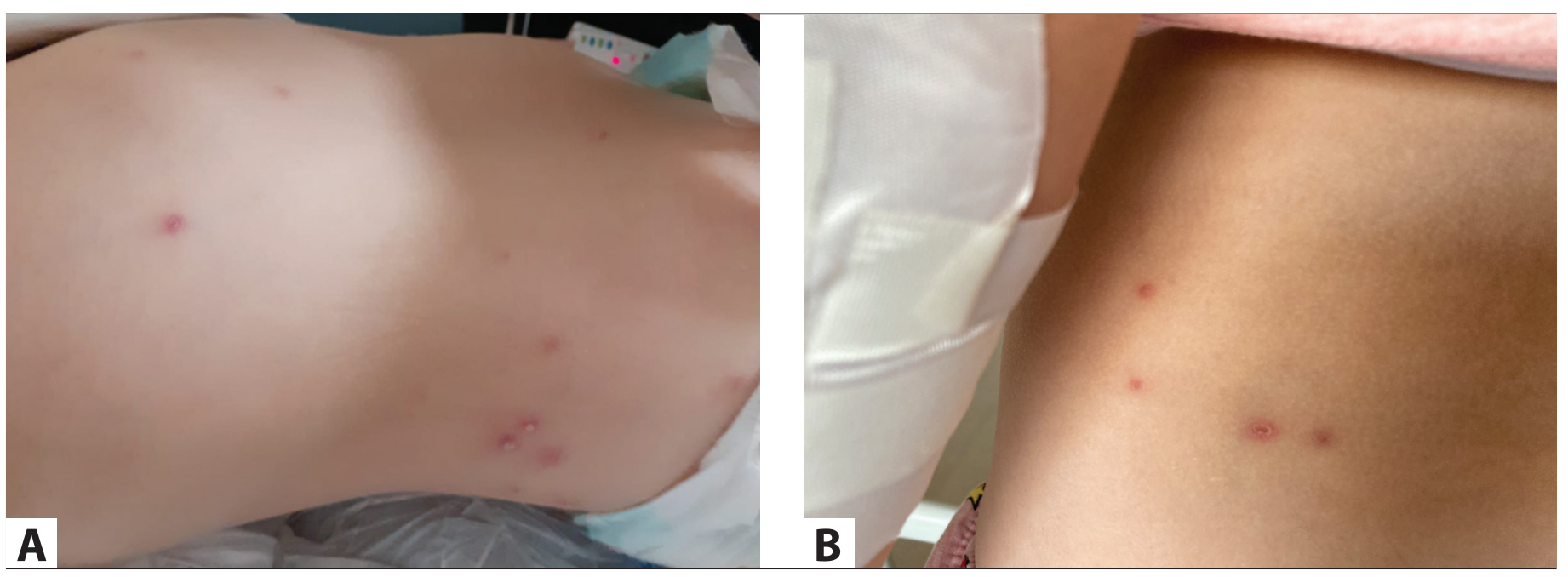

Figure 1. A. A few vesicular lesions on the trunk, B. A few crusted lesions on the trunk.

Correspondence Address/Yazışma Adresi Nurhayat Yakut

Başakşehir Çam ve Sakura Şehir Hastanesi,

Çocuk Enfeksiyon Hastalıkları Kliniği,

İstanbul-Türkiye

E-mail: nurhayatyakut@gmail.com 


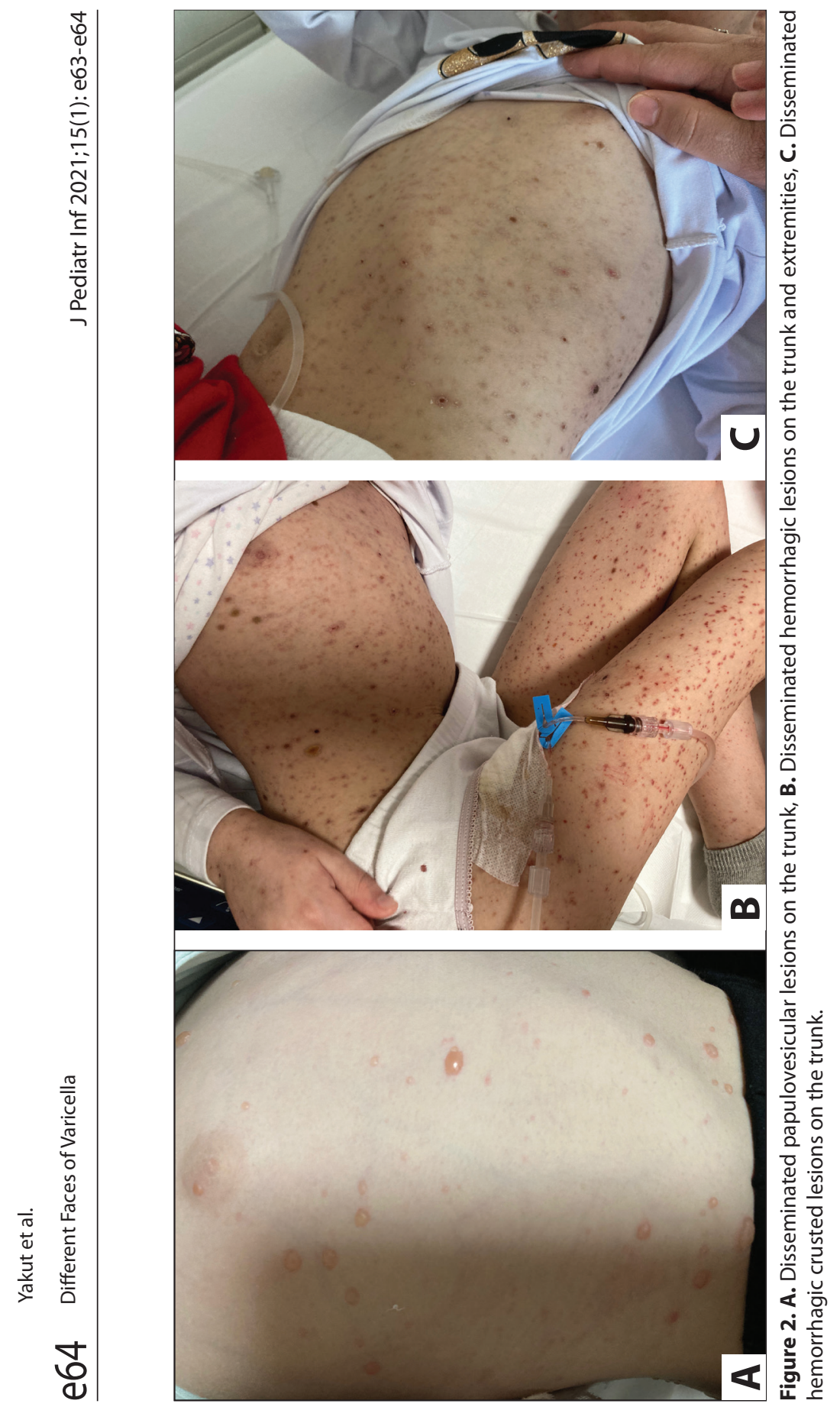

